\title{
Effective Resource Allocation, Millennium and Sustainable Development Goals in Nigeria
}

\author{
Ekiran Joseph Ojo (Ph.D)* \\ Department of Economics, School of Arts and Social Sciences, College of Education, Ikere-Ekiti, Ekiti State, \\ Nigeria.
}

*Corresponding Author: Ekiran Joseph Ojo (Ph.D), Department of Economics, School of Arts and Social Sciences, College of Education, Ikere-Ekiti, Ekiti State, Nigeria.

\begin{abstract}
This study identifies the challenges of Millennium Development Goals (MDGs) attainment in Nigeria, analyses the Sustainable Development Goals (SDGs) enabling conditions and examines measures for attaining SGD-poverty eradication goal in the country. The study presents Cocoon Prototype research design method and employs descriptive analytical technique to carry out the research objectives of the study. Likerttype scaling structured questionnaire research instrument was applied for data collection from 300 respondents, randomly selected. The result of the study discovered government's priority on SDGs enabling conditions as panacea for attaining SDG poverty eradication goal in Nigeria. The study concluded further that reformation of failed programmes and abandoned projects has significant positive impact on achieving $S G D$ s in Nigeria. The study therefore suggested that in order to achieve the SGD poverty eradication goal by 2030 in Nigeria, the government should ensure adequate provision of formidable enabling conditions as well as restructuring abandoned projects in her resources allocation policy implementation.
\end{abstract}

Key words: Effective Resources Allocation, Sustainable Development Goals, Cocoon Prototype Research Design.

\section{INTRODUCTION}

There are many underdeveloped nations in the world, including Nigeria with unstable and precarious development indices. About 1.2 billion people or about $20 \%$ of the world population live on less than US \$1 per day for survival (Jones, Wynn and Hillier, 2017).

World Bank Reports (1999) as in Aliyu (2001), literacy rate in Nigeria was 44\% in late 1990s and national net primary school enrolment was $81.19 \%$, meaning that about 19 out of every 100 primary school children were not in school (Kolawole, Adeigbe, Zaggi and Owonibi, 2014).

The global challenges among others became worrisome to the world leaders, specifically the United Nations. They therefore converged to develop a blueprint tagged the Millennium Development Goals (MDGs) visioned to meet the need of the undersigned nations. The MDGs blueprint was signed by 189 countries, including Nigeria, in New York in September 2000. The set goals were visioned to be achieved by every nation between the time limit spanning from year 2000 to 2015 (Kayode and Adeniran, 2012).

The Millennium Development Goals have eight goals as encapsulated below:

Table1. Millennium Development Goals (MDGs)

\begin{tabular}{|l|l|}
\hline MDGs S/N & MDGs Outline \\
\hline Goal 1 & Eradicate Extreme Poverty and Hunger \\
\hline Goal 2 & Achieve Universal Primary Education \\
\hline Goal 3 & Promote Gender Equality and Empower Women \\
\hline Goal 4 & Reduce Child Mortality \\
\hline Goal 5 & Improve Maternal Health \\
\hline Goal 6 & Combat HIV/AIDS, Malaria and Other Diseases \\
\hline Goal 7 & Ensure Environmental Sustainability \\
\hline Goal 8 & Develop a Global Partnership for Development \\
\hline
\end{tabular}

Source: United Nations (2008). 
Like many other underdeveloped countries, Nigeria after the adoption of the MDGs, was faced with the problem of raising the required needed financial resources for implementing the MDGs programme in an effective manner. The financial challenge persisted until 2005 when Nigeria obtained a debt relief of US $\$ 18$ billion from the Paris Club of creditors, while the debt balance of US\$ 12billion was paid by the Federal Government (Federal Republic of Nigeria, 2015). The debt relief gains were committed toward attaining the visioned MDGs in Nigeria through Ministries, Departments and Agencies. According to Ok oroa for and Anuforo (2012), many nations did not pursue the MDGs with as much momentum as others which led them to their 'backbencher' position. The bane of development in Nigeria is her inability to implement policies even when she is noted for beautiful policy formulation such as Independent Corrupt Practices Commission (ICPC) and Economic and Financial Crimes Commission (EFCC).

MDGs in Nigeria were faced with many challenges like oil price volatilities, corruption, intercommunal clashes, threat to internal security and lack of proper and effective policy implementation among others. The targets set for the MDGs therefore fell short of expectation in Nigeria as witnessed in some other countries of the world.

By September 2015, another plan of action for people, planet and prosperity called Sustainable Development Goals (SDGs) was ambitioned to cover the period between 2015 and 2030 for global development (Jones, Wynn and Hillier, 2017). In total, there are seventeen (17) SDGs and all governments were called by the United Nations to develop national strategies to pursue the attainment of the SDGs. The outline of the SDGs are as highlighted in Table 2 below:

Table2. Sustainable Development Goals (SDGs)

\begin{tabular}{|c|c|}
\hline $\begin{array}{l}\text { SDGs } \\
\text { S/N }\end{array}$ & SDGs Outline \\
\hline Goal 1 & End poverty in all its forms everywhere \\
\hline Goal 2 & End hunger, achieve food security and improved nutrition and promote sustainable agriculture \\
\hline Goal 3 & Ensure healthy lives and promote well-being for all at all ages \\
\hline Goal 4 & $\begin{array}{l}\text { Ensure inclusive and equitable quality education and promote lifelong learning opportunities for } \\
\text { all }\end{array}$ \\
\hline Goal 5 & Achieve gender equality and empower all women and girls \\
\hline Goal 6 & Ensure availability and sustainable management of water and sanitation for all \\
\hline Goal 7 & Ensure access to affordable, reliable, sustainable and modern energy for all \\
\hline Goal 8 & $\begin{array}{l}\text { Promote sustained, inclusive and sustainable economic growth, full and productive employment } \\
\text { and decent work for all }\end{array}$ \\
\hline Goal 9 & $\begin{array}{l}\text { Build resilient infrastructure, promote inclusive and sustainable industrialization and foster } \\
\text { innovation }\end{array}$ \\
\hline Goal 10 & Reduce inequality within and among countries \\
\hline Goal 11 & Make cities and human settlements inclusive, safe, resilient and sustainable \\
\hline Goal 12 & Ensure sustainable consumption and production patterns \\
\hline Goal 13 & Take urgent action to combat climate change and its impacts \\
\hline Goal 14 & Conserve and sustainably use the oceans, seas and marine resources for sustainable development \\
\hline Goal 15 & $\begin{array}{l}\text { Protect, restore and promote sustainable use of terrestrial ecosystems, sustainably manage forests, } \\
\text { combat desertification, and halt and reverse land degradation and halt biodiversity loss }\end{array}$ \\
\hline Goal 16 & $\begin{array}{l}\text { Promote peaceful and inclusive societies for sustainable development, provide access to justice } \\
\text { for all and build effective, accountable and inclusive institutions at all levels }\end{array}$ \\
\hline Goal 17 & $\begin{array}{l}\text { Strengthen the means of implementation and revitalize the global partnership for sustainable } \\
\text { development }\end{array}$ \\
\hline
\end{tabular}

Source: Https://sustainabledevelopment.un.org (2015).

Literatures reviewed on the Millennium Development Goals and Sustainable Development Goals in Nigeria revealed that most earlier studies either worked on MDGs or SDGs without reflecting the collaborative effects of the two vision programmes to ensure synergy in the implementation process toward achieving a common goal in the country. Among such studies are: Ajiye (2014), Lawal, Obasaju and Rotimi (2012), Kolawole, Adeigbe, Zaggi and Owonibi (2014), Pauw, Gericke, Olsson and Berglund (2015) and Vasiliki and Nikolaos (2019). This study is of the opinion that if the two programmes are co-existed in a research effort, a clearer position of the level of development and better integrated policy to attain the set development goals in the country will be presented. 
Unlike in many earlier studies like Sanjiv and Neeta (2016), Hulme (2009), Gwary (2011) and Thliza (2011) who broadly searched into all the 17 SDGs as outlined by the United Nations under a single research effort, this study adopts specific-goal analytical method with an attempt to make more indepth investigation that produces valid and robust inferences.

The MDGs and SDGs vision for poverty eradication goal shall be sampled for this study. The choice of the goal for the study is based on the prioritized position placed on the poverty eradication goal by the United Nations in the MDGs and SDGs outlines. The goal was enlisted on serial Number 1 of each of the vision programmes as presented in Tables 1 and 2 above.

In the process of bridging the above identified gaps in the literature, the specific objectives of the study are to: identify the challenges of MDGs attainment in Nigeria; analyse the SDGs enabling conditions; and examine measures for attaining SDG poverty eradication goal in the country.

\section{CONCEPTUAL AND EMPirical Literature}

\subsection{Empirical Literature}

Millennium Development Goals (MDGs) have been tagged the worlds quantified targets for addressing extreme poverty as well as promoting gender equality, education and environmental sustainability (Ajiye, 2014). According to Hulme (2009), human development and result based management are the major factors that significantly influence and shape the pattern of direction of MDGs. He observed that the factors were pursued as crucial variables to the survival of MDGs of a nation.

Jones et al (2017) opined that MDGs represent a new attempt to increase the effectiveness of development for poverty reduction with a time bound targets and strong commitment to monitor progress of attainment. By UNDP Report (2010), MDGs is the world's commitment to deal with global poverty in its many dimensions. Specifically, Mistry (2005), confirmed that MDGs are laudable projects aimed at poverty reduction.

Poverty in Nigeria can be described as poverty amidst plenty. This attests to the fact that the country is endowed with both natural and human resources which if wisely managed could facilitate the attainment of the MDGs. In an attempt to achieve the MDGs in the country, the government designed a number of policy documents such as National Economic Empowerment and Development Strategy (NEEDS) between 1999 and 2004 to lay a solid foundation for the implementation of the MDGs in Nigeria.

According to Ajiye (2014), as a way of bringing the reform programme closer to the people in Nigeria, each state government initiated State Economic Empowerment and Development Strategy (SEEDS). In his assessment, Okongwo (2009) emphasized that while NEEDS was struggling to position itself towards attaining certain goals through supporting small and medium scale enterprise accros the country, most of its states counterparts (SEEDS) merely existed on paper. It was projected that the sum of 44 trillion (\$28billion) was required yearly to achieve the visioned MDGs in Nigeria between year 2000 and 2015 (Nwokeoma, 2013). In actual fact, the country's MDGs office spent only $£ 1.23$ billion ( $\$ 305$ billion) towards meeting the MDGs targets between 2006 and 2009 (Ajiye, 2014).

It was observed by Falade (2008) that most African countries were backward in terms of implementing and executing MDGs projects, when compared with other regions of the world. This according to him was due to poor human resource capacity in formulating and monitoring the MDGs projects in the countries. As a complementary programme, Sustainable Development Goals (SDGs) was designed in 2015 to provide a broad consensus and common sense of purpose to sustainable development across the globe (Jones et al, 2017). Adelson, Engell, Ranalli and Van Anglen (2008) believes that SDGs are significant in improving water supply and sanitation, installing irrigation, protecting fragile environments and more generally in reducing poverty in many less developed economies.

For identification of area of targets, UNESCO (2014) has outlined a number of sub-themes to the economic, social and environmental dimensions of the SGDs: (1) economic perspectives, corporate responsibility, accountability, poverty reduction and market economy; (2) socio-cultural perspectives: cultural diversity, gender equality, human rights, health, governance, HIV/AIDs, peace and security; (3) environmental perspectives: climate change, national resources, mitigation, rural development, sustainable urbanization and disaster prevention. 


\subsection{Conceptual Clarification}

\subsubsection{Challenges of MDGs Implementation in Nigeria}

Nigeria, like many other undeveloped countries is exposed to various forms of challenges, some of these are highlighted within the conceptual framework below:

\section{$>$ Inadequate Finance}

During the MDGs period, Nigeria was faced with shortage of fund to implement the MDGs programmes in the country inspite of the gains of the debt relief received from the Paris Club of Creditors in 2005. For instance in October, 2009 the cost of financing the achievement of the MDGs in the country between 2010 and 2015 was estimated at US\$171 billion. The annual cost varied from US $\$ 19$ billion in 2010 to US\$38billion in 2015. On the contrary, an analysis of public expenditure allocations for achieving the MDGs during the period in Nigeria confirmed that the annual gap between the amount needed and the sum of money allocated for the MDGs programmes was as high as US\$17.7 billion (Ajiye, 2014).

\section{$>$ Security Challenges}

Internal security such as armed banditry, inter-communal clashes, kidnapping, herdsmen versus farmers' clashes, oil and gas pipeline vandalism and insurgencies such as Niger Delta militants and Boko Haram constituted the bane of progress on output and export during the MDGs period in Nigeria.

\section{$>$ Corruption and Indiscipline}

Every sector of Nigerian economy was dominated by gross indiscipline which gave birth to corruption practice during the MDGs programme. Government officials used their paraphernalia of office to divert funds required for the implementation of MDGs in the country to their personal uses.

\section{$>$ Natural Disasters}

Natural disasters such as desertification, flooding and erosion contributed largely to the domestic spending of the country during the MDGs programmes. This reduced the budgetary allocation of the government for the implementation of the MDGs in Nigeria.

\section{$>$ Ineffective Human Capacity}

MDGs programmes lacked effective human capacity for appropriate implementation and monitoring in Nigeria. Projects commissioned to meet the MDGs targets were poorly executed. Delays in processing certificates to award contracts, procurement and release of funds to contractors mostly led to abandoned projects of the MDGs in the country.

\section{$>$ Poor Governance}

Reference to Achebe (2001), the trouble with Nigerians is simply and squarely the failure of leadership. According to him, bad leadership in Nigeria affects policies implementation negatively as witnessed in the MDGs in the country.

\section{Problem of Data Collection}

Planning process for execution and implementation of projects for meeting the MDGs targets in Nigeria were very difficult. Most plans were misleading for unreliable data collected which has been a major problem of research activities in the less developed countries for long time.

\subsubsection{Achievements of Millennium Development Goals in Nigeria}

Notwithstanding the challenges faced during the implementation of MDGs in Nigeria, the selected success stories regarding to each of the development goals are shown below:

\section{MDG1: Eradicate Extreme Poverty and Hunger}

2015 Target: The proportion of people whose income is less than US\$1.0 a day was projected to decline to $21.4 \%$ by 2015 in Nigeria.

Attainment: Sourced from NBS-Revised Poverty Figures (2010), the 1992 poverty prevalence (42.7\%) rose to $53.3 \%$ and $45.5 \%$ in 2004 and 2010 respectively. The progress 
report in the country notwithstanding, the 2010 figure was $2.8 \%(45.5 \%-42.7 \%)$ points higher than the 1992 figure and $24.1 \%(45.5 \%$ - 21.4\%) points short of the 2015 MDGs target (Nigeria MDGs End-Point Report, 2015). These confirmed that the MDGs poverty target was not met as analysed above.

\section{MDG2: Achieve Universal Primary Education}

2015 Target: Children everywhere will be able to complete a full course of primary schooling.

Attainment: Sourced from Federal Ministry of Education (2015), primary school enrolment of 70\% (2001) declined to 59\% (2011) and further to 54\% (2013). It was also sourced that the primary six completion rate of $85 \%$ (2000) fell to $77 \%$ (2011) but rose to $82 \%$ (2013), leaving $18 \%$ to meet the $100 \%$ MDG completion target, set for 2015 in Nigeria.

\section{MDG3: Promote Gender Equality and Empower Women}

2015 Target: Eliminate gender disparities and achieve equity at all levels by 2015 .

Attainment: Reference to World Bank Statistics, there was a steady increase in the ratio of girls to boys in primary education in Nigeria from $82 \%$ in 1991 to $94 \%$ in 2013 . On the contrary, only $5.11 \%$ of the total seats in the National Parliament were held by women in Nigeria in 2015 as against the expected 35\% MDG 2015 target. In conclusion, the goal was not met especially in women employment but fair progress was observed on gender parity.

\section{MDG4: Reduce Child Mortality}

2015 Target: Reduce infant mortality rate to 30 deaths per 1000 live birth in Nigeria by 2015 .

Attainment: Infant mortality rate was 91deaths per 1000 live birth in 1990. This however decreased to $75,61,58$ deaths per live births in 2008, 2012 and 2014 respectively. The attainment of the goal fell short of MDG target of the 30 deaths per 1000 lives births in the country.

\section{MDG5: Improve Maternal Health}

2015 Target: Reduce by three Quarters the Proportion of women dying in childbirth.

Attainment: Reflecting from the Federal Republic of Nigeria (2015), the maternal mortality rate in Nigeria was 1000 deaths per 100,000 live births in 1990. The figure reduced consistently to 545 in 2008, 350 in 2012 and 243 per 100,000 live births in 2014. The 2015 MDG maternal mortality rate target was attained in Nigeria.

\section{MDG 6: Combat HIV and AIDS, Malaria and Other Diseases}

2015 Target: Halt and begin to reverse the incidence of HIV/AIDs, malaria and other major diseases.

Attainment: Reference to Kolawole et al (2014), since mid-1980s, the HIV/AIDs prevalence rate in Nigeria has continually on the increase from $1.8 \%$ to $5.8 \%$ in the period between 1991 and 2001 but decreased to $4.4 \%$ in 2005. Regarding the incidence of tuberculosis per 100,000 has fluctuated between 343 in 2005 and 339 in 2012 (Federal Republic of Nigeria, 2015). Generally, the target was not me during the MDGs period in Nigeria.

\section{MDG 7: Ensure Environmental Sustainability}

2015 Target: Reduce by half the proportion of people without access to clean drinking water and basic sanitation.

Attainment: The statistics provided by the UNICEF and WHO in the Nigeria MDGs End-Point Report (2015), it was confirmed that the proportion of households in Nigeria with access to safe drinking water was $69 \%$ in 2015 as against $40 \%$ in 1990. The report further confirmed that the numbers of Nigerians using improved sanitation facilities were $41 \%$ and $29 \%$ in 2014 and 2015 respectively. The country did not meet the 2015 MDG environmental sanitation target as indicated above. 


\section{MDG 8: Develop a Global Partnership for Development}

\section{Target: Develop further an open, rule-based and non-discriminatory trading system.}

Attainment: There was a rising trend in per capita official development assistance to Nigeria especially the debt relief of US\$ 18billion from Paris Club of Creditors in 2005. Cellular phone subscribers and tele-density per 100 people stood at 77.8 and 99.3 respectively in 2014. This led to tremendous growth in industrial sector during the MDGs vision period in Nigeria. The target for this goal was met as presented by the Nigeria MDGs End-Point Report (2015).

Conclusively, all the Millennium Development Goals were not met in Nigeria, except MDG 5 (Improve Maternal Health) and MDG 8 (Develop a global partnership for development). To overcome the challenges that hampered the full attainment of the 2015 MDGs in the country, a research based implementation framework for the newly introduced Sustainable Development Goals (SDGs) in the country for the period between 2015 and 2030 is mandatory.

\section{Method OF ANALYSIS}

This study employs Cocoon Prototype research design method adopted from Anita, Sebastian and Narayan (2013). The name Cocoon is derived from the butterfly analogy where a caterpillar needs to build a cocoon (the space required) in order to turn into a butterfly. The cocoon model for this study presents six main steps that are needed to be taken that will transform the post 2015 MDGs unsustainable development challenges in Nigeria to 2030. Sustainable Development Goals attainment: poverty eradication in focus. The brief of research design is shown in figure 1 below:

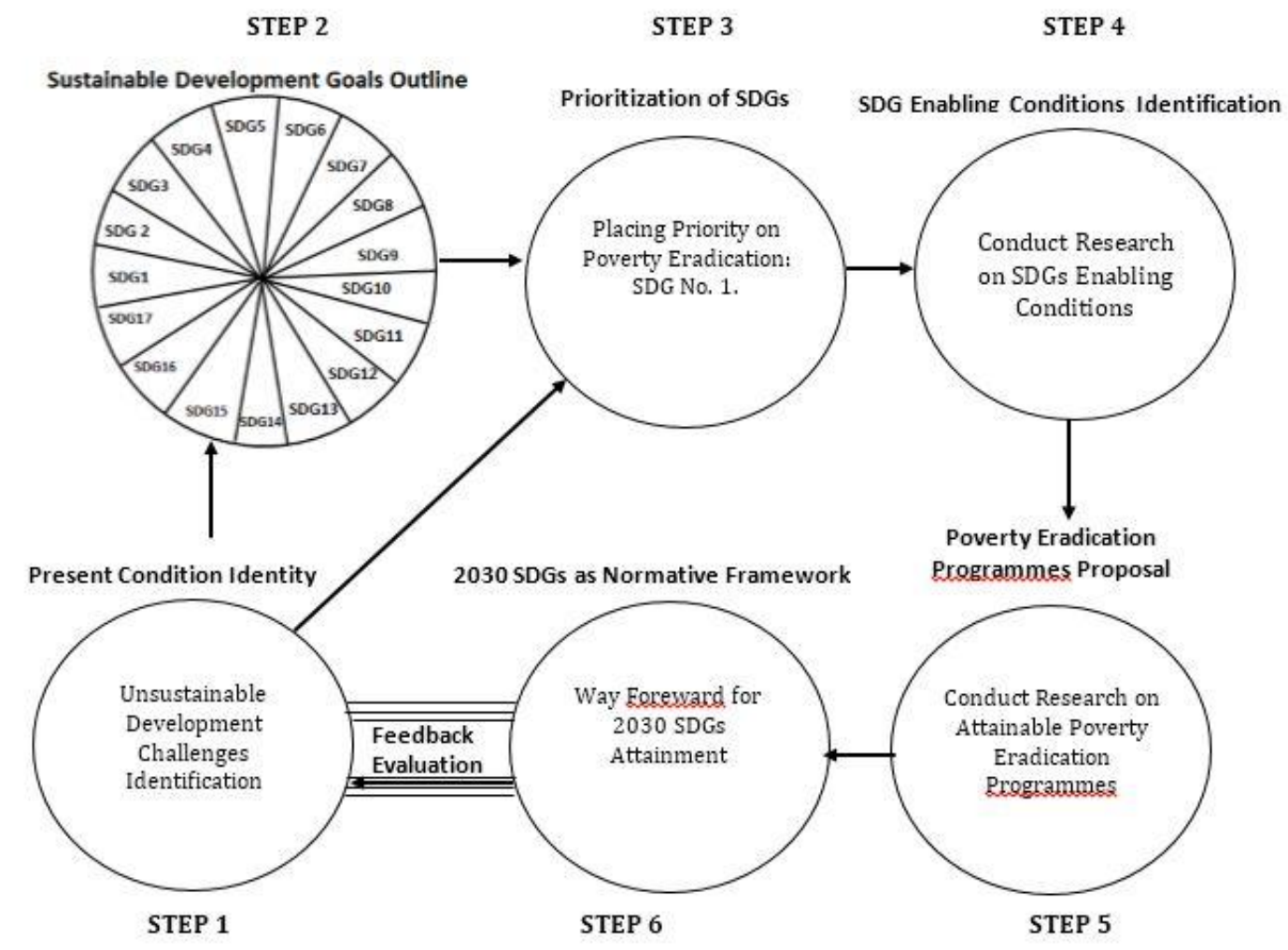

Figure1. Cocoon Prototype Transformation Process

Source: Author's Analysis, 2020

\section{Step1: Present Condition Identity}

This step identifies various goals that were not met during MDGs 2000-2015 period as highlighted in the literature as major unsustainable development challenges in Nigeria.

\section{Step2: Sustainable Development Goals Outline}

Step 2 of the study identifies in the literature the 17 sustainable development goals as outline by United Nations in September, 2015 for the purpose of further analysis in this study. 


\section{Step3: Prioritization of Sustainable Development Goals}

Here, the study places priority on poverty eradication of the SDG item 1, for an in-depth and a robust analysis in this study. The step links the research problem with the objectives of the study as reflected in steps 4 and 5 below.

\section{Step4: SDGs Enabling Conditions Identification}

The study carries out a research on SDGs enabling conditions in the country using descriptive approach, based on the nature of the variables in focus. Ekiti State was sampled, 300 respondents randomly selected and likert-type scaling structured questionnaire was employed. The instrument was based on two (2) point-scale: Agree (A) and Disagree (D).

\section{Step5: Poverty Eradication Programmes Proposal}

As presented in step 4 above, the researcher carries out an investigation to find out the list of viable investment programmes for the attainment of the targeted poverty eradication programme in Nigeria.

\section{Step6: 2030 SDGs as Normative Framework}

This step presents suggestions on the way forward for the 2030 SDGs attainment in the country. The report will be used to evaluate the performance of the SGDs programme's implementation in Nigeria after its expiration.

\subsection{Decision Rule}

The study uses 50\% (0.5) cut-off point for decision making on survey results. Any variable reflecting at least $50 \%$ acceptance responses of the total respondents shall be accepted as having the desired positive significant impact on the targeted development goal in Nigeria, and vice versa.

\subsection{Discussion of Findings}

\section{(a) SDGs Enabling Conditions}

Figure 2 below shows that all the enabling conditions observed in the study are significant to build formidable foundation for viable projects to be embarked upon by the government in order to attain poverty eradication sustainable development goal in Nigeria.

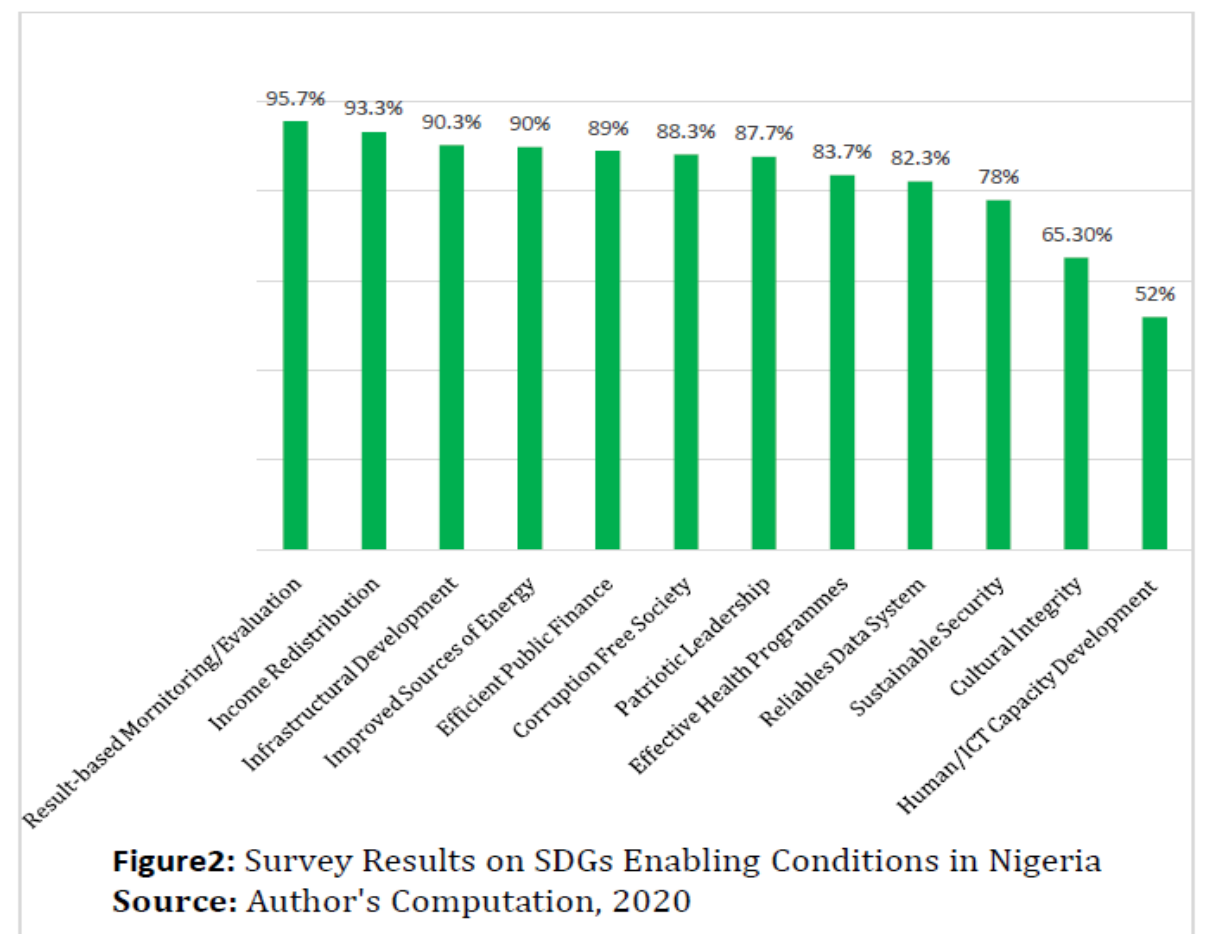

Thesurvey result reflects that $95.7 \%$ (287) respondents out of the total (300) respondents accepted that result-based monitoring and evaluation of SDGs has the tendency of providing enabling condition for achieving poverty eradication goal in the country. The result further reports that $93.3 \%, 90.3 \%$ and $90 \%$ of the total respondents for income redistribution, infrastructural development and improved sources of energy respectively were favourable conditions for poverty eradication projects in Nigeria. 
All other accepted conditions for achieving SDGs in the country as shown in figure 2, ranged between $52 \%$ and $89 \%$ of respondents of the total. The other enabling conditions are: efficient public finance, corruption free society, patriotic leadership, effective health programmes, reliable data system, sustainable security, cultural promotion and human capacity development.

\section{(b) SDGs Poverty Eradication Programmes}

Figure 3(a) presents the survey results on the investable projects for attaining SDGs in Nigeria. The result confirmed that $81.3 \%$ (244) respondents out of the total (300) respondents supported that reformation of abandoned projects in Nigeria shall make significant positive impact on SDG poverty eradication goal in the country. Such abandoned projects for reformation include: National Accelerated Food Production Programme (1972), Operation Feed the Nation (1976), Green Revolution Programme (1979), Go-Back to Land Programme (1984), and Better Life Programme (1987), among others.

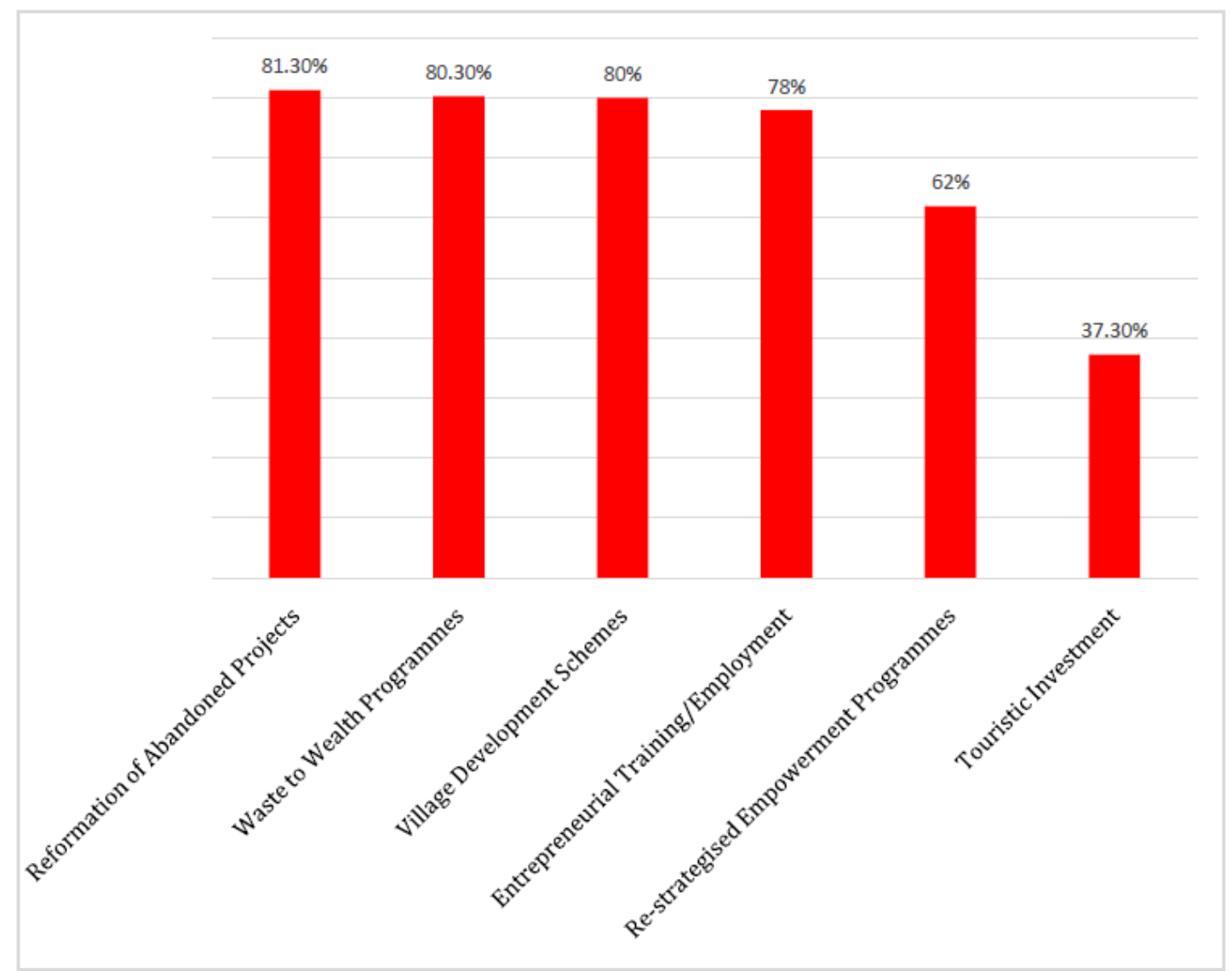

Figure2. Survey Results on SDGs Enabling Conditions in Nigeria.

Source: Author's Computation, 2020

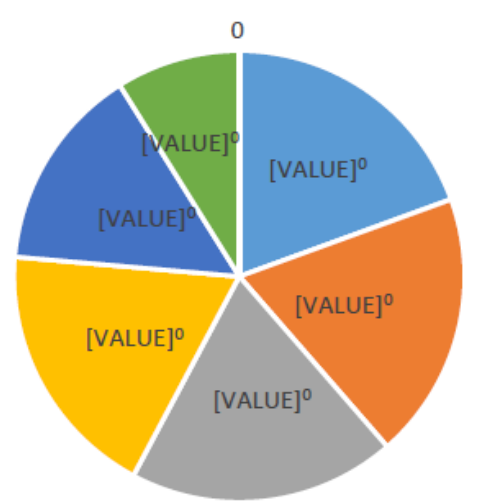

$$
\begin{aligned}
& \text { - } \alpha=\text { Reformation of Abandoned Projects } \\
& \text { - } \beta=\text { Waste to Wealth Programme } \\
& -\lambda=\text { Village Development Scheme } \\
& -X=\text { Entrepreneurial Education } \\
& \text { - } Y=\text { Restrategised Empowerment Programme } \\
& \text { - } Z=\text { Touristic Investment }
\end{aligned}
$$

Figure 3b: SDGs Poverty Eradication Programmes in Nigeria Source: Author's Computation, 2020 
The result in figure $3 \mathrm{a}$ further suggests that investing public fund on waste to wealth programmes (80.3\% of total respondents) and entrepreneurial training and employment (78\% respondents) would promote wealth of nation. Government financial commitment on village development schemes was also support by the study. Such programmes include: village health workers scheme, village infrastructure project and rural cooperative society.

The study agreed with $62 \%$ of total respondents that reviewing the government's empowerment programmes would impact sustainable development poverty eradication goal in Nigeria. These are: National Economic Empowerment and Development Strategy (NEEDS), State Economic Empowerment and Development Strategy (SEEDS) and Local Economic Empowerment and Development Strategy (LEEDS).

The report on touristic investment for achieving SDG poverty eradication goal in Nigeria was not favourable. Only $37.3 \%$ (112) respondents of the total (300) respondents were of the view that the variable could impact poverty eradication in the country. Touristic investment is therefore not a significant SDG poverty eradication programme since the $37.3 \%<50.0 \%$ bench mark.

Alternatively, the survey results described above are presented in pie chart method as contained in figure $3 \mathrm{~b}$ for clarity and further analysis.

\section{SUMMARY AND CONCLUSION}

Millennium Development Goals (MDGs) are series of eight time-bound development goals visioned in year 2000 to address poverty, education, gender equality, child mortality, diseases, maternal health, and environment global partnership, to be achieved in year 2015. In Nigeria, only child mortality and global partnership goals were met at the end of the MDGs programme. Sustainable Development Goals (SDGs), another globally seventeen time-bound development goals was visioned for the period between year 2015 and year 2030 .

This study searched into the enabling factors and feasible projects that can motivate the attainment of SDGs, specifically poverty eradication goal by year 2030 in Nigeria. The study concludes that for the SGD poverty eradication goal to be attained in the country, the following enabling condition should be put in place: result-based monitoring/evaluation, income redistribution, infrastructural development, improved sources of energy, efficient public finance, corruption free society, patriotic leadership, effective health programmes, reliable data system, sustainable security, cultural integrity and human capacity development.

The study further concluded that sustainable development poverty eradication goal shall be attained in Nigeria if the attention of the government is directed toward the following areas: reformation of abandoned projects, waste to wealth programme, village development scheme, entrepreneurial training/employment and re-strategised empowerment programme.

\section{SUGGESTIONS}

Based on the outcomes of this study, the under mentioned suggestions are proposed:

i. Government should ensure adequate provision of formidable enabling conditions in the process of attaining sustainable development poverty eradication goal in the country.

ii. Government should study the shortcomings of her abandoned projects and restructure such projects towards attaining sustainable development poverty eradication goal by year 2030 .

iii. Appropriate entrepreneurial training should be carried out by the government to reduce the rate of unemployment and thereby increase saving, investment and revenue for both the government and the private sector.

iv. Policy documents that initiated NEEDs, SEEDs and LEEDs during MDGs should be reviewed for better performance in order to impact positively for attainment of SDGs in Nigeria.

V. Government should place budgetary priority on rural development in the process of attracting agricultural products from the grass root for realization of SDGs in the country. 


\section{REFERENCES}

[1] Achebe, C. (2001). The Trouble with Nigeria. Paper for the UNUWIDER Conference on Sharing Ideas for Nigerians Prosperity, September, 2001.

[2] Adelson, G., Engell, J., Ranalli., \& Van Anglen, K. P. (2008). Environment: An Interdisciplinary Anthology. New Haven and London: Yale University Press.

[3] Ajiye, S. (2014). Achievements of Millennium Development Goals in Nigeria: A Critical Examination. International Affairs and Global Strategy, 25, 24-36.

[4] Aliyu, A. (2001). National Poverty Eradication Programme (NAPEP): Conception, Implementation, Coordination and Monitoring. Abuja, Nigeria: Siddwell Printers.

[5] Anita, B., Sebastian., \& Narayan, S. (2013). A Strategic and Transformative Approach to Education for Sustainable Development. A master's Degree Thesis in the School of Engineering, Blekinge Institute of Technology. Karlskrona, Sweden.

[6] Falade, J. B. (2008). Socio-Economic Policies and Millennium Development Goals (MDGs) in Africa: Analysis of Theory and Practices of MDGs. In Akinnawo, E. O. \&Ors. In socio-economic Policies and Millennium Development Goals in Africa, Hosted by Faculty of Social and Management of Sciences, AAU, Akungba, Akoko.

[7] Federal Ministry of Education (2015). 2014 Annual Report. Abuja: Federal Ministry of Education.

[8] Federal Republic of Nigeria (2015). Nigeria Millennium Development Goals, 2015 End-Point Report, Abuja.

[9] Gwary, M. M. (2011). Rural Area and Challenges for Millennium Development Goals (MDGs) in Nigeria. Edited by Adedoyin S. F., Ibadan and Ile-Ife, Nigeria: Andkolad Publishers Nigeria Limited.

[10] Hulme, D. (2009). The Millennium Development Goals (MDGs): A Short History of the World's Biggest Promise Manchester: Brooks World Poverty Institute.

[11] Jones, P., Wynn, M., \& Hillier, D. (2017). The Sustainable Development Goals and Information and Communication Technologies. Indonesian Journal of Sustainability, Accounting and Management, 1(1), $1-15$.

[12] Kayode, J., \&Adeniran, R. (2012). Nigeria Newspaper Coverage of the Millennium Development Goals: The Role of the Media. Itupale online Journal of Africa Studies, 4(1).

[13] Kolawole, T. O., Adeigbe, Y. K., Zaggi, Y. H., \&Owonibi, E. (2014). Millennium Development Goals (MDGs) in Nigeria: Issues and Problems. Global Journal of Human-Social Science: Sociology \& Culture, 14(5), 43-53.

[14] Lawal, A. I., Obasaju, B., \&Rotimi, E. M. (2012). Towards Achieving Millennium Development Goals (MDGs) in Nigeria: Prospect and Challenges. Journal of Economics and Sustainable Development, 3(9).

[15] Mistry, P. S. (2005). Reasons for Sub-Saharan Africa's Development Deficit, that the Commission for Africa did not consider. African Affairs, 104(417).

[16] NBC (National Bureau of Statistics) (2010). Revised Poverty Figures. Abuja: NBS.

[17] Nwokeoma, J. (2013). Nigeria and the MDGs: Beyond the Question of Funds. Available @ http:llwww.hollerafrica.com (21 $1^{\text {st }}$ June, 2013).

[18] Okongwo, E. (2009). Economic Empowerment in Nigeria: A Comparative Study of Economic Growth in Nigeria. Lagos: Business School.

[19] Okoroafor, E. C., \&Anuforo, E. E. (2012). The Millennium Development Goals (MDGs) and the Problem of Policy Implementation in Nigeria. International Journal of Development and Management Review, 7(1), 63-73.

[20] Pauw, B. P., Gericke, N.M., Olsson, D., \& Berglund, T. (2015). The Effectiveness of Education for Sustainable Development. Sustainability, (7), 15693-15717.

[21] Sanjiv, K., \& Neeta, K. (2016). Millennium Development Goals (MDGs) to Sustainable Development Goals (SDGs): Addressing Unfinished Agenda and Strengthening Sustainable Development and Partnership. Indian Journal of Community Medicine, 41(1), 1-4.

[22] Thliza, M. G. (2011). Millennium Development Goals (MDGs) and their Relevance in the Nigerian Context. Edited by Adedoyin S. F., Ibadan and Ile-Ife, Nigeria: Andkolad Publishers Nigeria Limited.

[23] UNDP (2010). Ghana Millennium Development Goals Report. By Ghana/National Development Planning Commission (NDPC) and United Nations Development Programme (UNDP).

[24] UNESCO (2014). Shaping the Future we want: UN Decade of Education for Sustainable Development. (2005 - 2014). Final Report.

[25] United Nations (2008). Report of the Secretary-General on the indicators for monitoring the Millennium Development Goals. E/C. 3/2008/29. New York. 
[26] Vasiliki, K., \&Nikolaos, V. (2019). Education for Sustainable Development: A Systemic Framework for Connecting the SDGs to Educational Outcomes. Sustainability, (11), 1-18.

\section{AUTHOR'S BIOGRAPHY}

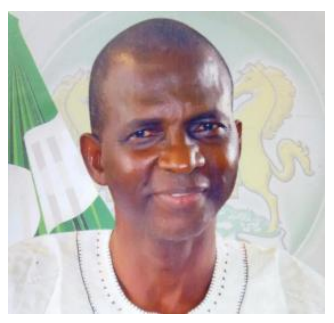

Ekiran Joseph Ojo, is a lecturer in the Department of Economics, School of Arts and Social Sciences, College of Education, Ikere-Ekiti, Ekiti State, Nigeria

Citation: Ekiran Joseph Ojo (Ph.D). "Effective Resource Allocation, Millennium and Sustainable Development Goals in Nigeria" International Journal of Humanities Social Sciences and Education (IJHSSE), vol 7, no. 6, 2020, pp. 26-36. doi: http://dx.doi.org/10.20431/2349-0381.0706004.

Copyright: (C) 2020 Authors. This is an open-access article distributed under the terms of the Creative Commons Attribution License, which permits unrestricted use, distribution, and reproduction in any medium, provided the original author and source are credited. 